\title{
Study of Dexmedetomidine in Caudal Block for Children Undergoing Inguino-scrotal Surgery
}

\author{
Gautam B, Piya B, Karki D
}

Department of Anesthesiology and Intensive Care

Kathmandu Medical College Teaching Hospital,

Sinamangal, Kathmandu.

\section{Corresponding Author}

Binod Gautam,

Department of Anesthesiology and Intensive Care Kathmandu Medical College Teaching Hospital,

Sinamangal, Kathmandu, Nepal.

E-mail: gautambinod@hotmail.com

\section{Citation}

Gautam B, Piya B, Karki D. Study of Dexmedetomidine in Caudal Block for Children Undergoing Inguino-scrotal Surgery. Kathmandu Univ Med J. 2020;69(1):68-73

\section{ABSTRACT}

\section{Background}

Caudal block is the most common anaesthetic technique employed in children for managing perioperative pain of inguino-scrotal surgery. However, despite using longacting local anaesthetics, caudal analgesia lasts relatively shorter. Dexmedetomidine, an alpha-2 agonist, augments local anaesthetic action.

\section{Objective}

To assess the analgesic effect of caudal Dexmedetomidine.

\section{Method}

This is a randomized, double-blinded study conducted on otherwise healthy children (one to five years) undergoing elective inguino-scrotal surgery. General anaesthesia was administered and a laryngeal mask airway was inserted for assisting ventilation. The caudal block was applied using 0.8 milliliters/kilogram drug volume comprising either two milligrams/kilogram Bupivacaine in group $A(n=42)$ or two milligrams/ kilogram Bupivacaine mixed with 0.75 micrograms/kilogram Dexmedetomidine in group B ( $n=42$ ). Intraoperatively, inhaled Halothane, intravenous Fentanyl, fluids, and ventilation were titrated to maintain monitored hemodynamic variables within $15 \%$ from baseline values. The primary endpoint comprised the duration of analgesia, defined by a time when postoperative pain score (face, legs, activity, cry, consolability; FLACC scale) reached four out of ten. Perioperative events were studied for 24 hours. Student's t-test and Chi-square test were used for analysis, with $\mathrm{p}$-value less than 0.05 considered as significant.

\section{Result}

Demographic, surgical, and anaesthetic characteristics were similar between the groups. Duration of analgesia was significantly prolonged in group B (group B, $413 \pm 101$ minutes; group $A, 204 \pm 40$ minutes). The intraoperative requirement for supplement Fentanyl was significantly reduced in group B. Adverse events were comparable between the groups.

\section{Conclusion}

Dexmedetomidine prolongs the duration of analgesia when mixed with caudal Bupivacaine, without increasing adverse events.

\section{KEY WORDS}

Adjuncts, Analgesia, Caudal block, Children, Dexmedetomidine, Paediatric 


\section{INTRODUCTION}

Caudal block (CB) is performed by instilling local anaesthetic (LA) into the lowermost epidural space through the sacral hiatus. Pre-incision $C B$ is the most common regional analgesic technique used for a variety of paediatric surgeries. ${ }^{1,2}$ It provides excellent pain relief in the postoperative period. However, in majority children pain develops after the LA effect resolves by the first four hours. $^{3,4}$

Efforts to find better adjuncts to caudal LA, which improve analgesia with minimal side effects continue. Ketamine, Fentanyl, and Clonidine mixed with caudal LA have been studied for prolonging postoperative analgesia in children. ${ }^{1,5,6}$ Despite efficacy, opioids including Fentanyl and Morphine are not universally accepted owing to their higher association with itching, vomiting, and hypoventilation. , $7,8^{-1}$ Dexmedetomidine, a newer alpha-2 adrenergic receptor agonist that possesses a better receptor selectivity when compared to Clonidine, is shown to prolong the action of caudal LA. ${ }^{9,10}$ Caudal Dexmedetomidine has been claimed to lack adverse effects and to provide beneficial sedation in children postoperatively. But studies employing Dexmedetomidine as a caudal adjunct to Bupivacaine for perioperative analgesia are not available in Nepalese children.

The primary objective of this study was to assess the duration of analgesia provided by 0.75 micrograms/ kilogram Dexmedetomidine admixed with caudal Bupivacaine in children undergoing unilateral inguinoscrotal surgery. Studying the occurrence of perioperative events for 24 hours comprised the secondary objective.

\section{METHODS}

This was a randomized, double-blinded, equal allocation, interventional study conducted from January to October 2019 at the operating room and postanaesthetic care unit (PACU) of a medical college. Ethical clearance was taken from the Institutional Review Committee (Ref: 231120186). Written informed consent was taken from the parents.

Eighty-four American Society of Anesthesiologists (ASA) physical status one (I) children aged one to five years, from both gender and weighing up to 20 kilograms (kg), who were undergoing elective surgery for unilateral inguinal hernia or hydrocele were enrolled in the study. Participants fasted six hours for solid feeds, four hours for breast milk, and two hours for clear fluids prior to surgery.

Children having upper respiratory tract infections, bleeding diathesis, anomalies, deformities or active infection in sacrum or spine, allergy to Bupivacaine or Dexmedetomidine, and taking any other study drug, analgesics or sedatives within 24 hours prior to the intervention were excluded. The inability to perform the block and CB failure also comprised the exclusion criteria.
The sample size $(n)$ estimation for each group was based on the primary outcome measure, the duration of analgesia. To detect two hours of clinically important difference (d) in the duration of analgesia, its standard deviation (SD) of 2.8 hours was taken from a previous study. ${ }^{9}$ The following formula was used.

$\mathrm{n}=\left(2(Z \alpha+Z \beta)^{2} S D^{2}\right) / d^{2}$

Forty-two subjects were calculated for each group keeping $90 \%$ power $(Z \beta=1.282)$ and an alpha value of $0.05(Z \alpha=1.96)$. The closed-envelop method was employed to randomly allocate 42 participants into each group.

In the preoperative waiting area, children not tolerating parental separation received an intramuscular injection of 0.1 milligrams $(\mathrm{mg})$ per $\mathrm{kg}$ Midazolam premedication, 15 minutes before entering the operating room. General anaesthesia was induced with a gradually increased concentration of inhaled Halothane in Oxygen before achieving intravenous (IV) access. IV Fentanyl 0.5 micrograms $(\mathrm{mcg})$ per $\mathrm{kg}$ and a titrated Propofol dose ensured the anaesthetic depth for inserting laryngeal mask airway. Ventilation was assisted manually using the JacksonRees modification of Ayre's T-piece breathing circuit and the fresh gas flow rate was adjusted for maintaining continually monitored end-tidal carbon dioxide tension (flow-through system) between 30 and $40 \mathrm{mmHg}$.

The study drug was prepared in 10 milliliters ( $\mathrm{ml}$ ) unlabeled syringes by the principal investigator. It was handed over to the investigators who were blinded to the group allocation and were responsible for performing the intervention, patient care, and assessment of study outcomes. Under the strict aseptic precautions and patient in the left lateral position, the landmark-guided entry of 25 gauge hypodermic needle into caudal space was confirmed clinically and with swoosh test. ${ }^{11}$ Group $A(n=42)$ received a caudal injection of two $\mathrm{mg} / \mathrm{kg}$ Bupivacaine diluted in Normal Saline to make a volume of $0.8 \mathrm{ml} / \mathrm{kg}$. Group B $(\mathrm{n}=42)$ received two $\mathrm{mg} / \mathrm{kg}$ Bupivacaine mixed with 0.75 $\mathrm{mcg} / \mathrm{kg}$ Dexmedetomidine diluted in Normal Saline to make a volume of $0.8 \mathrm{ml} / \mathrm{kg}$. The caudal injection was performed over two minutes. Both the parent and participants were unaware of the study drug. Each participant received a perrectal suppository of Paracetamol $30 \mathrm{mg} / \mathrm{kg}$. The surgical skin incision was allowed 10 minutes after the intervention.

Heart rate $(H R)$, non-invasive systolic arterial pressure (SAP) and arterial oxygen saturation $\left(\mathrm{SPO}_{2}\right)$ were recorded at the preoperative waiting area (baseline), immediately before surgical incision (pre-incision), every five minutes throughout surgery and every 30 minutes in the PACU. The highest $H R$ and SAP reached during the first five minutes after skin incision (post-incision) were also recorded. The monitored hemodynamic parameters were aimed to keep within $15 \%$ of baseline by titrating the anaesthetic depth (Halothane concentration of $3 \%$ maximum), supplement Fentanyl (maximum of two $\mathrm{mcg} / \mathrm{kg}$ ), ventilation and fluids. 
CB failure was defined when post-incision hemodynamic parameters could not be controlled as aimed despite using maximum doses of Halothane and Fentanyl. Bradycardia and hypotension (HR and SAP reduction of more than 15\% from their respective baseline values), medications used, infused fluid volume, and blood loss were recorded.

Duration of anaesthesia was defined as the time from anaesthesia induction to Halothane discontinuation, done when skin suturing completed. LMA was removed once the spontaneous breathing was adequate. The time from Halothane discontinuation to the patient's opening of eyes on gentle auditory stimulus was defined as emergence time. Thereafter, patients were transferred to PACU and reunited with their parents.

Continual monitoring of children in PACU was done by a dedicated nurse and parents, who were instructed to report unarousable children. In conjunction with parents, the investigators utilized face, legs, activity, cry, consolability (FLACC) scale, as necessary, to determine the child's first need for analgesic (Table 1). ${ }^{12}$ Duration of analgesia was defined by the time from caudal injection till the FLACC score reached four, at which the first analgesic was administered and regularly thereafter. Postoperative adverse events including respiratory depression $\left(\mathrm{SPO}_{2}\right.$ less than 95\%), urinary retention, leg-weakness, vomiting, and any other were recorded as yes/no variables for 24 hours.

Table 1. Face, legs, activity, cry, consolability (FLACC) scale ${ }^{12}$

\begin{tabular}{|c|c|c|c|}
\hline Categories & Scoring 0 & Scoring 1 & Scoring 2 \\
\hline Face & $\begin{array}{l}\text { No particular } \\
\text { expression } \\
\text { or smile }\end{array}$ & $\begin{array}{l}\text { Occasional gri- } \\
\text { mace or frown, } \\
\text { withdrawn, } \\
\text { disinterested }\end{array}$ & $\begin{array}{l}\text { Frequent } \\
\text { to constant } \\
\text { quivering chin, } \\
\text { clenched jaw }\end{array}$ \\
\hline Legs & $\begin{array}{l}\text { Normal position } \\
\text { or relaxed }\end{array}$ & $\begin{array}{l}\text { Uneasy, restless, } \\
\text { tense }\end{array}$ & $\begin{array}{l}\text { Kicking or legs } \\
\text { drawn up }\end{array}$ \\
\hline Activity & $\begin{array}{l}\text { Lying quietly, } \\
\text { normal position, } \\
\text { moves easily }\end{array}$ & $\begin{array}{l}\text { Squirming, shift- } \\
\text { ing back and } \\
\text { forth, tense }\end{array}$ & $\begin{array}{l}\text { Arched, rigid or } \\
\text { jerking }\end{array}$ \\
\hline Cry & $\begin{array}{l}\text { No cry (awake } \\
\text { or asleep) }\end{array}$ & $\begin{array}{l}\text { Moans or whim- } \\
\text { pers; occasional } \\
\text { complaint }\end{array}$ & $\begin{array}{l}\text { Crying steadily, } \\
\text { screams or } \\
\text { sobs, frequent } \\
\text { complaints }\end{array}$ \\
\hline Consolability & Content, relaxed & $\begin{array}{l}\text { Reassured by } \\
\text { occasional } \\
\text { touching, } \\
\text { hugging or } \\
\text { being talked to, } \\
\text { distractable }\end{array}$ & $\begin{array}{l}\text { Difficult to } \\
\text { console or } \\
\text { comfort }\end{array}$ \\
\hline
\end{tabular}

Each of the five categories Face, Legs, Activity, Cry and Consolability is scored from zero to two, which results in a total score between zero and ten.

Data were analyzed with a statistical package for social science evaluation version 20 (IBM-SPSS Inc; Chicago, Illinois, USA). Participants who had a change in management or missing data were omitted from the analysis. Quantitative variables including the duration of analgesia were presented as mean (standard deviation) and were compared between the groups using Student's t-test. Nominal categorical variables including the occurrence of perioperative events were presented as number (percentage) and relative risk (95\% confidence interval) and were analyzed with the Chisquare test. A p value of less than 0.05 (two-tailed) was considered statistically significant.

\section{RESULTS}

The caudal block was possible in all participants and no episode of intrathecal, intravenous, or subcutaneous injection was witnessed. Throughout the study period, there was no occurrence of major cardio-respiratory events. There was no $\mathrm{CB}$ failure and all participants completed the study protocol to be included in the final analysis. Demographic, surgical, and anaesthetic characteristics of participants distributed between the two groups were similar (Table 2).

Table 2. Demographic and operative data

\begin{tabular}{|c|c|c|c|}
\hline Variable & Group A $(n=42)$ & Group B $(n=42)$ & P value \\
\hline Age (years) ${ }^{*}$ & $3.11(1.23)$ & $3.45(1.40)$ & 0.25 \\
\hline Gender $^{+}$(Male:Female) & 39: 3 (92.8: 7.1) & 39: 3 (92.8: 7.1) & 1.00 \\
\hline Weight (kilograms) ${ }^{*}$ & $14.40(2.86)$ & $15.02(3.17)$ & 0.35 \\
\hline Surgical diagnosis $^{+}$ & $37: 5$ & $35: 7$ & 0.75 \\
\hline $\begin{array}{l}\text { (Inguinal hernia: Hy- } \\
\text { drocele) }\end{array}$ & (88: 12) & (83.3: 16.6) & \\
\hline Baseline $\mathrm{HR}^{*}$ & $110.98(15.25)$ & $113.14(18.68)$ & 0.562 \\
\hline Baseline SAP ${ }^{*}$ & 94.79 (9.99) & $93.62(10.42)$ & 0.602 \\
\hline $\begin{array}{l}\text { Midazolam premedica- } \\
\text { tion }^{+}\end{array}$ & $9(21.4)$ & $15(35.7)$ & 0.227 \\
\hline $\begin{array}{l}\text { Propofol dose (mil- } \\
\text { ligrams) }\end{array}$ & $45.12(20.46)$ & $48.57(30.53)$ & 0.544 \\
\hline $\begin{array}{l}\text { Duration of anesthesia } \\
\text { (minutes) }^{*}\end{array}$ & $55.52(11.55)$ & $52.52(10.66)$ & 0.22 \\
\hline $\begin{array}{l}\text { Intraoperative blood } \\
\text { loss }(\mathrm{ml})^{*}\end{array}$ & $4.62(1.84)$ & $5.07(2.02)$ & 0.28 \\
\hline $\begin{array}{l}\text { Intraoperative fluid } \\
\text { infused }(\mathrm{ml})^{*}\end{array}$ & 241.79 (121.87) & $229.76(116.16)$ & 0.64 \\
\hline \multicolumn{4}{|c|}{$\begin{array}{l}{ }^{*} \text { mean (standard deviation), }{ }^{+} \text {number (percentage), } \mathrm{HR}=\text { heart rate in } \\
\text { beats/minute, } \mathrm{SAP}=\text { systolic arterial pressure in } \mathrm{mmHg}, \mathrm{p} \text {-value }<0.05 \\
\text { is significant }\end{array}$} \\
\hline
\end{tabular}

During surgery, requirements for supplement Fentanyl was significantly reduced in group $B$, whereas adverse events were comparable between the groups (Table 3). The duration of analgesia in group B was significantly longer compared to group A (Table 4). In PACU, no child was reported to be unarousable, and adverse events were similar between the groups.

\section{DISCUSSION}

The finding of the study demonstrates that the children who received Dexmedetomidine in the caudal block were pain-free for a significantly longer duration after surgery than those who were only given Bupivacaine. In addition, 
Table 3. Intraoperative events

\begin{tabular}{|c|c|c|c|c|}
\hline Event & $\begin{array}{l}\text { Group A } \\
(n=42)\end{array}$ & $\begin{array}{l}\text { Group B } \\
(n=42)\end{array}$ & $\begin{array}{l}\text { Relative } \\
\text { risk }(\mathrm{Cl})\end{array}$ & $P$ value \\
\hline Pre-incision $\mathrm{HR}^{*}$ & $\begin{array}{l}107.02 \\
(15.63)\end{array}$ & $\begin{array}{l}106.71 \\
(15.46)\end{array}$ & & 0.928 \\
\hline Post-incision $\mathrm{HR}^{*}$ & $\begin{array}{l}107.69 \\
(14.31)\end{array}$ & $\begin{array}{l}105.19 \\
(18.13)\end{array}$ & & 0.485 \\
\hline Pre-incision SAP* & $92.26(9.85)$ & 86.95 (8.78) & & 0.011 \\
\hline Post-incision SAP* & $93.98(10.58)$ & $86.81(9.98)$ & & 0.002 \\
\hline $\begin{array}{l}\text { Need for supple- } \\
\text { ment Fentanyl }\left.\right|^{+}\end{array}$ & 11 (26.1) & $2(4.7)$ & $\begin{array}{l}5.50 \\
(1.29- \\
23.32)\end{array}$ & 0.010 \\
\hline $\begin{array}{l}\text { Supplement } \\
\text { Fentanyl (micro- } \\
\text { gram } / \mathrm{kg})^{*}\end{array}$ & $3.21(5.92)$ & $0.6(3.16)$ & & 0.013 \\
\hline $\begin{array}{l}\text { Atropine for } \\
\text { bradycardia }^{+}\end{array}$ & $3(7.1)$ & $5(11.9)$ & $\begin{array}{l}1.66 \\
(0.42- \\
6.53)\end{array}$ & 0.713 \\
\hline $\begin{array}{l}\text { Vasopressor for } \\
\text { hypotension }^{+}\end{array}$ & $3(7.1)$ & $6(14.2)$ & $\begin{array}{l}2.00 \\
(0.53- \\
7.47)\end{array}$ & 0.483 \\
\hline
\end{tabular}

"mean (standard deviation), ${ }^{\dagger}$ number (percentage), $\mathrm{Cl}=95 \%$ confidence interval, $\mathrm{HR}=$ heart rate in beats/minute, $\mathrm{SAP}=$ systolic arterial pressure in $\mathrm{mmHg}$, $\mathrm{p}$-value $<0.05$ is significant

Table 4. Postoperative events

\begin{tabular}{|c|c|c|c|c|}
\hline Event & $\begin{array}{l}\text { Group A } \\
(n=42)\end{array}$ & $\begin{array}{l}\text { Group B } \\
(n=42)\end{array}$ & $\begin{array}{l}\text { Relative } \\
\text { risk }(\mathrm{Cl})\end{array}$ & $P$ value \\
\hline $\begin{array}{l}\text { Emergence time } \\
\text { (minutes) }^{*}\end{array}$ & $22.83(5.96)$ & $25.05(8.28)$ & & 0.164 \\
\hline $\begin{array}{l}\text { Duration of analge- } \\
\text { sia (minutes)* }\end{array}$ & $\begin{array}{l}204.67 \\
(40.39)\end{array}$ & $\begin{array}{l}413.83 \\
(101.87)\end{array}$ & & 0.000 \\
\hline Urinary retention ${ }^{+}$ & $3(7.1)$ & $4(9.5)$ & $\begin{array}{l}1.33 \\
(0.31- \\
5.59)\end{array}$ & 1.000 \\
\hline Vomiting $^{+}$ & $4(9.5)$ & $6(14.2)$ & $\begin{array}{l}1.50 \\
(0.45- \\
4.93)\end{array}$ & 0.738 \\
\hline Leg weakness ${ }^{\dagger}$ & $3(7.1)$ & $3(7.1)$ & $\begin{array}{l}1.00 \\
(0.21- \\
4.67)\end{array}$ & 1.000 \\
\hline
\end{tabular}

"mean (standard deviation), ${ }^{\dagger}$ number (percentage), $\mathrm{Cl}=95 \%$ confidence interval, $p$-value $<0.05$ is significant

Dexmedetomidine significantly reduced intraoperative requirement for supplement Fentanyl without an added risk of adverse events for 24 hours.

Dexmedetomidine possesses sympatholytic, sedative, and analgesic properties. It has found its safe and effective applications in many anaesthetic, sedative, and analgesic regimens for children. ${ }^{13}$ The role of alpha-2 adrenergic receptors in modulating spinal-mediated analgesia is established well for many decades..$^{14,15}$ Their stimulation secondary to epidural administration of agonists decreases calcium entry and neurotransmitter release from nerve terminals, which underlie the mechanism for facilitating the analgesic action of caudal Dexmedetomidine. ${ }^{16,17}$ Long history of proven efficacy of Clonidine as a neuraxial adjuvant has paved the pathway for the use of Dexmedetomidine, a newer alpha-2 agonist. A much higher receptor selectivity of Dexmedetomidine, in comparison to Clonidine, might evidence its superiority in enhancing LA action, in addition to a better side effect profile. ${ }^{18,19}$

Results of the prolonged duration of analgesia with caudal Dexmedetomidine in our study are supported by various studies. ${ }^{9,10,20}$ A recently published meta-analysis that included 10 randomized controlled trials has suggested a promising role of Dexmedetomidine when added to the caudal Bupivacaine in prolonging postoperative analgesia in children without an increase in side effects. ${ }^{21}$ Caudal Dexmedetomidine is shown to prolong analgesia comparable to that of caudal Morphine, with the added advantage of absent hypoventilation. ${ }^{22}$ With the similar demographic, surgical and anaesthetic characteristics, and despite receiving less intraoperative Fentanyl, group $B$ patients in our study showed a significantly prolonged analgesia compared to group $A$, which can only be attributed to Dexmedetomidine. Significantly reduced intraoperative requirement for supplement Fentanyl in group B is explained by a prior finding that caudal Dexmedetomidine minimizes the response to surgical traction of inguinal hernia sac. ${ }^{23}$

On contrary to our results, a previous study on caudal Dexmedetomidine for paediatric cardiac surgery showed a significantly increased incidence of bradycardia and hypotension. ${ }^{24}$ Inclusion of participants other than ASA I physical status undergoing cardiac surgery and the use of comparatively larger caudal drug volume in that study were probably responsible. In our study, even though the pre-incision and post-incision SAP in group $B$ were both significantly lower in comparison to group $A$, the need for vasopressor was similar (Table 3). Like our finding, many studies on caudal Dexmedetomidine have not reported a significantly increased need for medications to treat bradycardia and hypotension. ${ }^{9,10,20-23}$

The strengths of the present study comprised of the inclusion of similar types of surgery and the absence of modifications in the anaesthesia practice at our set up except for one group of children receiving a small-dose of caudal Dexmedetomidine in addition. Neonates and infants were excluded from the study to avoid a potential risk of dural puncture owing to their higher association with anatomic variations of the sacral hiatus and sacral cornua. ${ }^{25}$ And, our study was restricted to children who were still small (up to $20 \mathrm{~kg}$ ) enough for their parents to carry, so as to avoid problems of fall and injury even if they develop postoperative leg-weakness. Similarly, the FLACC scale, we used, is a well-accepted, reliable, and valid instrument to assess pain in children. ${ }^{12,21,26} \mathrm{And}$, a postoperative pain trigger was set at a FLACC score of more than three, which coincides with many of the similar studies included in a meta-analysis. ${ }^{21}$

The caudal drug volume and Bupivacaine's dose used in our study were within the current recommendation. ${ }^{1,3,7}$ Absence of CB failure and no increment in post-incision hemodynamic 
parameters in both the groups further demonstrate the proper application of CB (Table 3). In children, IV doses between 0.5 and two $\mathrm{mcg} / \mathrm{kg}$ Dexmedetomidine have been recommended for perioperative analgesia. ${ }^{13}$ Doses up to two $\mathrm{mcg} / \mathrm{kg}$ are reported for its caudal administration. ${ }^{10,20-22}$ A dose-response study on Dexmedetomidine as a caudal adjunct showed that all the doses including $0.5,1.0$, and $1.5 \mathrm{mcg} / \mathrm{kg}$ significantly prolonged the analgesia duration in comparison to the caudal LA alone, whereas the highest dose was more frequently associated with postoperative sedation. ${ }^{27}$ We employed a dose on the lower side of the mentioned range, which might explain the lack of difference in emergence time between the two groups (Table 4). Further, group A patients receiving a significantly higher amount of intraoperative supplement Fentanyl might have been contributory. All of the children were transferred to the PACU only after they emerged from anaesthesia and as none of them were unarousable thereafter, assessing their pain did not pose a difficulty for the investigators.

Postoperative pain, agonizing suffering for children, represents a major source of dissatisfaction among parents and caregivers and is considered a measure of the quality of anaesthesia care. Preventing pain whenever possible, using multi-modal analgesia, works well for most patients. For its ease of performance, safety, efficacy, and advantages, single-shot CB continues to be the preferred perioperative analgesic technique for children. To further prolong the analgesia provided by caudal Bupivacaine and with no added side effects, we recommend $0.75 \mathrm{mcg} / \mathrm{kg}$

\section{REFERENCES}

1. Wiegele $\mathrm{M}$, Marhofer $\mathrm{P}$, Lonnqvist PA. Caudal epidural blocks in paediatric patients: a review and practical considerations. $\mathrm{Br} J$ Anaesth. 2019;122(4):509-17.

2. Polaner DM, Taenzer AH, Walker BJ, Bosenberg A, Krane EJ, Suresh $S$, et al. Pediatric Regional Anesthesia Network (PRAN): a multiinstitutional study of the use and incidence of complications of pediatric regional anesthesia. Anesth Analg. 2012;115(6):1353-64.

3. Dobereiner EF, Cox RG, Ewen A, Lardner DR. Evidence-based clinical update: which local anesthetic drug for pediatric caudal block provides optimal efficacy with the fewest side effects? Can J Anaesth. 2010;57(12):1102-10

4. Shanthanna H, Singh B, Guyatt G. A systematic review and metaanalysis of caudal block as compared to noncaudal regional techniques for inguinal surgeries in children. Biomed Res Int. 2014;2014:890626.

5. Khakurel S, Sapkota S, Karki AJ. Analgesic effect of caudal bupivacaine with or without clonidine in pediatric patient. J Nepal Health Res Counc. 2019;16(41):428-33.

6. Singh J, Shah RS, Vaidya N, Mahato PK, Shrestha S, Shrestha BL. Comparison of ketamine, fentanyl and clonidine as an adjuvant during bupivacaine caudal anaesthesia in paediatric patients. Kathmandu Univ Med J. 2012;39(3):25-9.

7. Vittinghoff M, Lonnqvist PA, Mossetti V, Heschl S, Simic D, Colovic $\mathrm{V}$, et al. Postoperative pain management in children: guidance from the pain committee of the European Society for Paediatric Anaesthesiology (ESPA Pain Management Ladder Initiative). Paediatr Anaesth. 2018;28(6):493-506.

8. Karl HW, Tyler DC, Krane EJ. Respiratory depression after low-dose caudal morphine. Can J Anaesth. 1996;43(10):1065-7. caudal Dexmedetomidine to be also studied in children other than ASA physical status I and those undergoing other infra-umbilical surgeries. Also, a study using inhaled Nitrous Oxide for intraoperative analgesia that could avoid systemic analgesics, an important confounder of postoperative analgesia duration seems logical.

The absence of a control group with IV Dexmedetomidine did not allow us to comment on its potential local effect, which comprised the major limitation of the study, along with our inability to use ultrasound-guidance for the intervention. In addition, even though the strict provision of 10 minutes interval from $C B$ to surgical incision was exercised, a lack of objective assessments for a failed, incomplete or unilateral block and the anaesthetic depth comprised the other limitation such that titration of supplement Fentanyl and Halothane was solely based on clinical parameters. Similarly, in the absence of endtidal Halothane concentration measurement, the effect of caudal Dexmedetomidine on anaesthetic requirement could not be ascertained.

\section{CONCLUSION}

As a component of multi- modal analgesia, Dexmedetomidine $0.75 \mathrm{mcg} / \mathrm{kg}$ when mixed with Bupivacaine used for pre-incisional single-shot caudal block in anaesthetized children significantly prolongs analgesia following inguino-scrotal surgery, without adding a risk of adverse events.

9. Saadawy I, Boker A, Elshahawy MA, Almazrooa A, Melibary S, Abdellatif $A A$, et al. Effect of dexmedetomidine on the characteristics of bupivacaine in a caudal block in pediatrics. Acta Anaesthesiol Scand. 2009;53(2):251-6.

10. El-Hennawy AM, Abd-Elwahab AM, Abd-Elmaksoud AM, El-Ozairy HS, Boulis SR. Addition of clonidine or dexmedetomidine to bupivacaine prolongs caudal analgesia in children. Br J Anaesth. 2009;103(2):26874.

11. Orme RM, Berg SJ. The 'swoosh' test-an evaluation of a modified 'whoosh' test in children. Br J Anaesth. 2003;90(1):62-5.

12. Merkel SI, Voepel-Lewis T, Shayevitz JR, Malviya S. The FLACC: a behavioral scale for scoring postoperative pain in young children. Pediatr Nurs. 1997;23(3):293-7.

13. Plambech $M Z$, Afshari A. Dexmedetomidine in the pediatric population: a review. Minerva Anestesiol. 2015;81(3):320-32.

14. Yaksh TL, Reddy SV. Studies in the primate on the analgesic effects associated with intrathecal actions of opiates, alpha-adrenergic agonists and baclofen. Anesthesiology. 1981;54(6):451-67.

15. Eisenach JC, Grice SC, Dewan DM. Epinephrine enhances analgesia produced by epidural bupivacaine during labor. Anesth Analg. 1987;66(5):447-51.

16. Asano T, Dohi S, Ohta S, Shimonaka H, lida H. Antinociception by epidural and systemic alpha(2)-adrenoceptor agonists and their binding affinity in rat spinal cord and brain. Anesth Analg. 2000;90(2):400-7.

17. Eisenach JC, De Kock M, Klimscha W. Alpha(2)-adrenergic agonists for regional anesthesia: a clinical review of clonidine (1984-1995). Anesthesiology. 1996;85(3):655-74. 
18. Yoshitomi T, Kohjitani A, Maeda S, Higuchi H, Shimada M, Miyawaki T. Dexmedetomidine enhances the local anesthetic action of lidocaine via an alpha-2A adrenoceptor. Anesth Analg. 2008;107(1):96-101.

19. Bajwa SJ, Bajwa SK, Kaur J, Singh G, Arora V, Gupta S, et al. Dexmedetomidine and clonidine in epidural anaesthesia: a comparative evaluation. Indian J Anaesth. 2011;55(2):116-21.

20. Anand VG, Kannan M, Thavamani A, Bridgit MJ. Effects of dexmedetomidine added to caudal ropivacaine in paediatric lower abdominal surgeries. Indian J Anaesth. 2011;55(4):340-6.

21. Tu Z, Tan X, Li S, Cui J. The efficacy and safety of dexmedetomidine combined with bupivacaine on caudal epidural block in children: a meta-analysis. Med Sci Monit. 2019;25:165-73.

22. El Shamaa HA, Ibrahim M. A comparative study of the effect of caudal dexmedetomidine versus morphine added to bupivacaine in pediatric infra-umbilical surgery. Saudi J Anaesth. 2014;8(2):155-60.
23. Xiang Q, Huang DY, Zhao YL, Wang GH, Liu YX, Zhong L, et al. Caudal dexmedetomidine combined with bupivacaine inhibit the response to hernial sac traction in children undergoing inguinal hernia repair. $\mathrm{Br} J$ Anaesth. 2013;110(3):420-4.

24. Nasr DA, Abdelhamid HM. The efficacy of caudal dexmedetomidine on stress response and postoperative pain in pediatric cardiac surgery. Ann Card Anaesth. 2013;16(2):109-14.

25. Sekiguchi M, Yabuki S, Satoh K, Kikuchi S. An anatomic study of the sacral hiatus: a basis for successful caudal epidural block. Clin J Pain. 2004;20(1):51-4.

26. Manworren RC, Hynan LS. Clinical validation of FLACC: preverbal patient pain scale. Pediatr Nurs. 2003;29(2):140-6.

27. Bharti N, Praveen R, Bala I. A dose-response study of caudal dexmedetomidine with ropivacaine in pediatric day care patients undergoing lower abdominal and perineal surgeries: a randomized controlled trial. Paediatr Anaesth. 2014;24(11):1158-63. 